\title{
Data report: underway geophysics ${ }^{1}$
}

\author{
Moo-Hee Kang, ${ }^{2}$ William W. Sager, ${ }^{3}$ and the Expedition 324 Scientists $^{3}$
}

\section{Chapter contents}

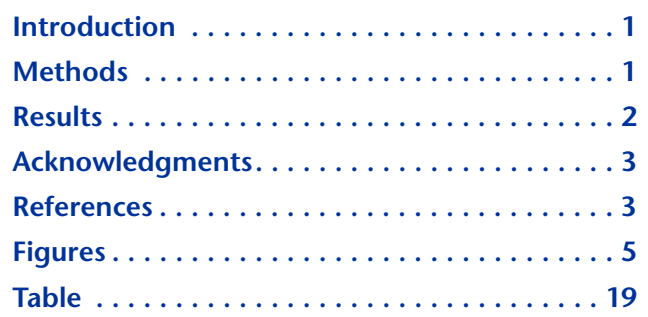

${ }^{1}$ Kang, M.-H., Sager, W.W., and the Expedition 324 Scientists, 2010. Data report: underway geophysics. In Sager, W.W., Sano, T., Geldmacher, J., and the Expedition 324 Scientists, Proc. IODP, 324: Tokyo (Integrated Ocean Drilling Program Management International, Inc.). doi:10.2204/iodp.proc.324.108.2010 2 Petroleum and Marine Division, Korea Institute of Geoscience and Mineral Resources, 92 Gwahangno, Yuseong-gu, Daejeon 305-350, Korea. karl@kigam.re.kr

${ }^{3}$ Expedition 324 Scientists' addresses.

\section{Introduction}

Integrated Ocean Drilling Program Expedition 324 had long transits from Yokohama, Japan, to Shatsky Rise; between the five sites; and from Shatsky Rise to Townsville, Australia. In all, transits took approximately one-third of the entire time allotted for the expedition. Underway geophysical data were collected in international waters during transit and between drill sites. Bathymetry and magnetic data were collected using a $3.5 \mathrm{kHz}$ CHIRP/echosounder and marine magnetometer, respectively (Fig. F1). A gyrocompass and a Global Positioning System (GPS) navigation system were used for positioning the bathymetric and magnetic data.

\section{Methods}

\section{Navigation}

The GPS navigation system was used throughout Expedition 324. A Trimble DSM232 GPS receiver was used as the primary navigation device. GPS positions were continuously updated at $1 \mathrm{~s}$ intervals and subsampled at 1 min intervals with a WINFROG software system. Subsequent processing and display of navigation data were performed using the Generic Mapping Tools software package (Wessel and Smith, 1995).

\section{CHIRP/echo-sounder}

A $3.5 \mathrm{kHz}$ CHIRP/echo-sounder was used to acquire bathymetric data as well as high-resolution subbottom seismic reflection data. The $3.5 \mathrm{kHz}$ system uses a SyQwest Bathy-2010 echo-sounder system driven by a single EDO-type 323c transducer. The transducer is mounted in a sonar dome located $45.5 \mathrm{~m}$ forward of the ship's moonpool. Digital bathymetry and Society of Exploration Geophysicists (file format " $Y$ ") subbottom seismic data were recorded on the SyQwest Bathy-2010 echo-sounder system during all transits.

\section{Marine magnetometer}

Total intensity measurements of the Earth's magnetic field were obtained with a Geometrics Model G-886 proton precession marine magnetometer towed $\sim 300 \mathrm{~m}$ astern. Magnetic data were recorded at $3 \mathrm{~s}$ intervals and then reduced to 1 min intervals with 
navigation data produced by the WINFROG navigation software. In order to measure the effect of the ship's magnetic field with heading, a circular survey $(\sim 7 \mathrm{~km}$ in diameter) was conducted while in transit from Site U1349 to Site U1350 between Universal Time Coordinated (UTC) $1055 \mathrm{~h}$ and $1215 \mathrm{~h}$ on 12 October 2009 (Fig. F2). This method was proposed by Bullard and Mason (1961). The equation for predicting the effect of the ship's magnetic field is:

$$
F_{\mathrm{Q}}=F+\mathrm{C}_{0}+\mathrm{C}_{1} \cos \theta+\mathrm{C}_{2} \cos 2 \theta+\mathrm{S}_{1} \sin \theta+\mathrm{S}_{2} \sin 2 \theta,
$$

where $\theta$ is the ship's heading measured clockwise from north, $F_{\mathrm{Q}}$ is the total field at location $Q, F$ is the ambient magnetic field, and $\mathrm{C}_{0}, \mathrm{C}_{1}, \mathrm{C}_{2}, \mathrm{~S}_{1}$, and $\mathrm{S}_{2}$ are constants dependent on the ship's magnetic properties (Bullard and Mason, 1961). For a symmetrical ship, the sine terms are negligible compared with the cosine terms; therefore, we set $S_{1}$ and $S_{2}$ to 0 . To minimize diurnal effects, the survey calibration circle was conducted at night (time difference between local time and UTC is $+10 \mathrm{~h}$ ). The circular survey was conducted over a relatively flat portion of seafloor (depth variation between 3242 and $3342 \mathrm{~m}$ ) (Fig. F3). Even though the International Geomagnetic Reference Field (IGRF) values around the circular survey show only $40 \mathrm{nT}$ differences (from 41,851 to $41,950 \mathrm{nT}$ ), the maximum differences observed are as much as $100 \mathrm{nT}$ (from 41,723 to 41,823 nT). The measured magnetic data were plotted versus magnetic heading, and a best fit curve was computed (Fig. F4). The computed heading correction constants $\mathrm{C}_{0}, \mathrm{C}_{1}$, and $\mathrm{C}_{2}$ of the $\mathrm{R} / \mathrm{V}$ JOIDES Resolution from $300 \mathrm{~m}$ astern are

$$
\begin{gathered}
\mathrm{C}_{0}=48.16, \\
\mathrm{C}_{1}=-52.61, \text { and } \\
\mathrm{C}_{2}=4.45 .
\end{gathered}
$$

Thus, the magnetic field errors generated by the ship $\left(F_{\mathrm{H}}\right)$ are expressed as

$$
F_{\mathrm{H}}=48.16-52.61 \cos \theta+4.45 \cos 2 \theta .
$$

The obtained constants $\mathrm{C}_{0}$ and $\mathrm{C}_{1}$ are higher than previously reported results $\left(\mathrm{C}_{0}=-3.2\right.$ to $5.5 ; \mathrm{C}_{1}=$ -12.9 to -3.0$)$ measured from other research vessels (Bullard and Mason, 1961; Buchanan et al., 1996). Higher constants are expected because of the length of the JOIDES Resolution compared to the lengths of other research ships. Even though the magnetometer was towed $300 \mathrm{~m}$ astern, this distance is not sufficient to avoid the ship's magnetic effect. The acquired total fields were reduced to magnetic anoma- lies using the 10th generation IGRF coefficients (McLean et al., 2004; Maus et al., 2005). Before correction of the ship's heading effect, the maximum track crossover errors are as much as $48 \mathrm{nT}$ (root mean square $[\mathrm{RMS}]=20 \mathrm{nT}$ ) at track crossings. After the ship's heading effect was corrected, the crossovers are reduced to $13 \mathrm{nT}(\mathrm{RMS}=9 \mathrm{nT})$. Herein, we provide the results from both before and after the ship's heading correction.

\section{Results}

During Expedition 324, bathymetry data and marine magnetic data were collected for $8559 \mathrm{~km}$ (Fig. F5). The transits of the expedition were divided into six legs and named sequentially (Transits EXP324-L1TEXP324-L6T) for convenient identification of each transit (Table T1).

\section{Bathymetry}

Shatsky Rise contains three large volcanic massifs (Tamu, Ori, and Shirshov), and the flanks of these massifs typically have gentle slopes of $\sim 1.5^{\circ}$ (Sager et al., 1999) (Fig. F6). During the first transit (EXP324L1T) from Yokohama to Site U1346, the ship passed over the Japan Trench, a deep abyssal plain, and the northern flank of the Ori Massif and ended at the summit of Shirshov Massif (Figs. F6, F7). The deepest part of the Japan Trench is deeper than 7000 meters below sea level (mbsl), with a $\sim 2.6^{\circ}$ slope angle, whereas the water depth of the abyssal plain ranges from 5900 to $5600 \mathrm{mbsl}$, except over a seamount $\left(36^{\circ} 48.7970^{\prime} \mathrm{N}, 154^{\circ} 04.8012^{\prime} \mathrm{E}\right)$, which shallows up to $5200 \mathrm{mbsl}$. The northern flank of the Ori Massif has a gentle surface with some high peaks and shallows toward the Shirshov Massif. The seafloor bathymetry between Sites U1346 and U1347 (Transit EXP324L2T) is characterized by several seamounts that shoal to between 3900 and 3500 mbsl, jutting from a flat plain at $~ 5000$ mbsl ("Sliter Basin") (Fig. F8). The third transit (EXP324-L3T), from Sites U1347 to U1348, crossed the northeast flank of Tamu Massif, where water depth varies between 3000 and 3500 mbsl (Fig. F9). Bathymetry data were collected over the summit of "Cooperation Seamount" while in transit between Sites U1348 and U1349 (Transit EXP324-L4T). The seamount has a steep flank and twin peaks with the shallowest depth at $2700 \mathrm{mbsl}$, as reported by Sager et al. (1999) (Fig. F10). The summit of Ori Massif is flat, and the flanks have a gentle slope angle of $\sim 1.2^{\circ}$ on Transit EXP324-L5T (Fig. F11). After drilling at Site U1350, the ship moved to the southwest to pass over a high feature $(4400 \mathrm{~m})$ within Helios Basin (Transit EXP324-L6T). The ship then turned to the south over the western summit of 
Tamu Massif (Fig. F12A). The summit has a broad, dome-shaped feature, and the southern flank of the massif has $\mathrm{a} \sim 2^{\circ}$ slope toward the south. The depth of the ocean floor surrounding the Shatsky Rise is deeper than $5500 \mathrm{mbsl}$, and some sea knolls rise a few hundred meters from the floor. The ship continued to move toward the south and crossed the Marcus-Wake and Magellan seamount chains, which developed around the Jurassic Quiet Zone (Fig. F5). The Marcus-Wake Seamounts show a west-northwest trend, and numerous seamounts are scattered over $\sim 400 \mathrm{~km}$. Most of them have pointed peaks, but some have flat tops (guyots) (Fig. F12B). Likewise, the Magellan Seamounts show a trend of northnorthwest to south-southeast, and seamounts rise above the surrounding ocean floor at $\sim 6000 \mathrm{mbsl}$. The ship passed through the Caroline Islands located on the southern margin of the Mariana Basin and over the western flank of Ontong Java Plateau, where water depth ranges from 4000 to 2000 mbsl (Figs. F5, F12C). Between the Ontong Java Plateau and the Solomon Islands, the Kilinailau Trench lies with an $~ 30$ $\mathrm{km}$ width. The Soloman Island arc is separated from Solomon Basin by the New Britain Trench, the deepest point of which reaches below 7500 mbsl. Bathymetry of Solomon Basin generally shoals to the south up to $4000 \mathrm{mbsl}$. Another deep submarine basin, Woodlark Basin, is located between Woodlark and Pocklington ridges.

\section{Magnetic anomalies}

Magnetic anomalies over the abyssal plain west of Shatsky Rise vary from -250 to $250 \mathrm{nT}$ and show mostly positive anomalies except in a location over a seamount (Fig. F7). However, near the northern part of Ori Massif, the magnetic anomalies are again negative with low values of about $-380 \mathrm{nT}$. The summit of Shirshov Massif shows anomalies of -50 to $100 \mathrm{nT}$, and between the southwestern flank of the Shirshov Massif and the northern flank of Tamu Massif, anomalies vary from -250 to $250 \mathrm{nT}$ (Fig. F8). At the northern flank margin of Tamu Massif, anomalies fluctuate highly (between -400 and $400 \mathrm{nT}$ ) and show mainly positive values toward the western slope of the massif (Site U1347). Magnetic anomalies in transit from Site U1347 to Site U1348 show positive values up to $250 \mathrm{nT}$ (Fig. F9). In the confines of Helios Basin, magnetic data show high positive anomalies up to $450 \mathrm{nT}$, whereas over Cooperation Seamount, magnetic data show weakly negative anomalies (Fig. F10). On the summit of Ori Massif, magnetic anomalies vary between -150 and $150 \mathrm{nT}$ (Fig. F11). Anomalies between Ori and Tamu massifs fluctuate from -250 to $250 \mathrm{nT}$, but show mainly positive anomalies in the summit area of Tamu Massif
(Fig. F12A). On the southern slope of Tamu Massif, magnetic anomalies show a deep trough of $-300 \mathrm{nT}$ and fluctuate with mostly positive values toward the abyssal plain where the Hawaiian magnetic lineations are developed (Fig. F12A). However, from $\sim 1100 \mathrm{~km}$ along the transit from Site U1350 to Townsville over the Hawaiian lineations, magnetic anomalies have very low amplitudes, except in the regions of seamounts (Marcus-Wake and Magellan seamount chains) (Fig. F12A, F12B). The area where magnetic anomalies show low-amplitude features in the western part of the mid-Pacific plate is known as the Jurassic Quiet Zone (Tominaga et al., 2008) (Fig. F5). These low-amplitude anomalies continued southward to the Caroline Islands north of the Ontong Java Plateau. At the Caroline Islands, magnetic data show an anomalous high peak up to $800 \mathrm{nT}$, whereas in the vicinity of the western flank of Ontong Java Plateau, magnetic anomalies vary between -150 and 150 nT (Fig. F12C). Deep troughs of negative magnetic anomalies less than $-350 \mathrm{nT}$ are shown in the southwestern margin of Ontong Java Plateau near the Kilinailau Trench and the Soloman Island arc. Magnetic anomalies in the Solomon and Woodlark basins also show mostly negative values, but some high peaks of positive anomalies ( 250 nT) are observed around the Pocklington Ridge (Fig. F12C).

\section{Acknowledgments}

This research used data provided by the Integrated Ocean Drilling Program (IODP). We thank the technical staff and crew of the JOIDES Resolution during Expedition 324 for their expertise, which made marine geophysical data collection possible. We also thank H.-C. Han and J.-S. Hwang of Korea Institute of Geoscience and Mineral Resources for advice on analyzing ship's heading effect on the magnetic measurements. We are grateful to Benjamin HornerJohnson for his helpful suggestions to improve this manuscript. This study was supported by the Korea IODP grant from the Ministry of Land, Transport, and Maritime Affairs, Korea.

\section{References}

Buchanan, S.K., Scrutton, R.A., Edwards, R.A., and Whitmarsh, R.B., 1996. Marine magnetic data processing in equatorial regions off Ghana. Geophys. J. Int., 125(1):123-131. doi:10.1111/j.1365246X.1996.tb06539.x

Bullard, E.C., and Mason, R.G., 1961. The magnetic field astern of a ship. Deep-Sea Res., 8(1):20-27. doi:10.1016/ 0146-6313(61)90012-0 
General Bathymetric Chart of the Oceans, 2008. The GEBCO_08 Grid: Liverpool (British Oceanographic Data Centre). http://www.gebco.net/data_and_products/ gridded_bathymetry_data/documents/gebco_08.pdf

Maus, S., Macmillan, S., Chernova, T., Choi, S., Dater, D., Golovkov, V., Lesur, V., Lowes, F., Lühr, H., Mai, W., McLean, S., Olsen, N., Rother, M., Sabaka, T., Thomson, A., and Zvereva, T., 2005. The 10th-generation International Geomagnetic Reference Field. Geophys. J. Int., 161(3):561-565. doi:10.1111/j.1365-246X.2005.02641.X

McLean, S., Macmillan, S., Maus, S., Lesur, V., Thomson, A., and Dater, D., 2004. The US/UK World Magnetic Model for 2005-2010. NOAA Tech. Rep., NESDIS/NGDC1. http://www.geomag.bgs.ac.uk/documents/ wmm_2005.pdf

Nakanishi, M., Sager, W.W., and Klaus, A., 1999. Magnetic lineations within Shatsky Rise, northwest Pacific Ocean: implications for hot spot-triple junction interaction and oceanic plateau formation. J. Geophys. Res., [Solid Earth], 104(B4):7539-7556. doi:10.1029/1999JB900002
Sager, W.W., Kim, J., Klaus, A., Nakanishi, M., and Khankishieva, L.M., 1999. Bathymetry of Shatsky Rise, northwest Pacific Ocean: implications for ocean plateau development at a triple junction. J. Geophys. Res., [Solid Earth], 104(4):7557-7576. doi:10.1029/1998JB900009

Tominaga, M., Sager, W.W., Tivey, M.A., and Lee, S.-M., 2008. Deep-tow magnetic anomaly study of the Pacific Jurassic Quiet Zone and implications for the geomagnetic polarity reversal timescale and geomatic field behavior. J. Geophy. Res., [Solid Earth], 113(B7):B07110. doi:10.1029/2007JB005527

Wessel, P., and Smith, W.H.F., 1995. New version of Generic Mapping Tools released. Eos, Trans. Am. Geophys. Union, 76(33):329. doi:10.1029/95E000198

Initial receipt: 9 April 2010

Acceptance: 1 July 2010

Publication: 3 November 2010

MS 324-108 
Figure F1. Illustration of underway geophysical data acquisition during Expedition 324.

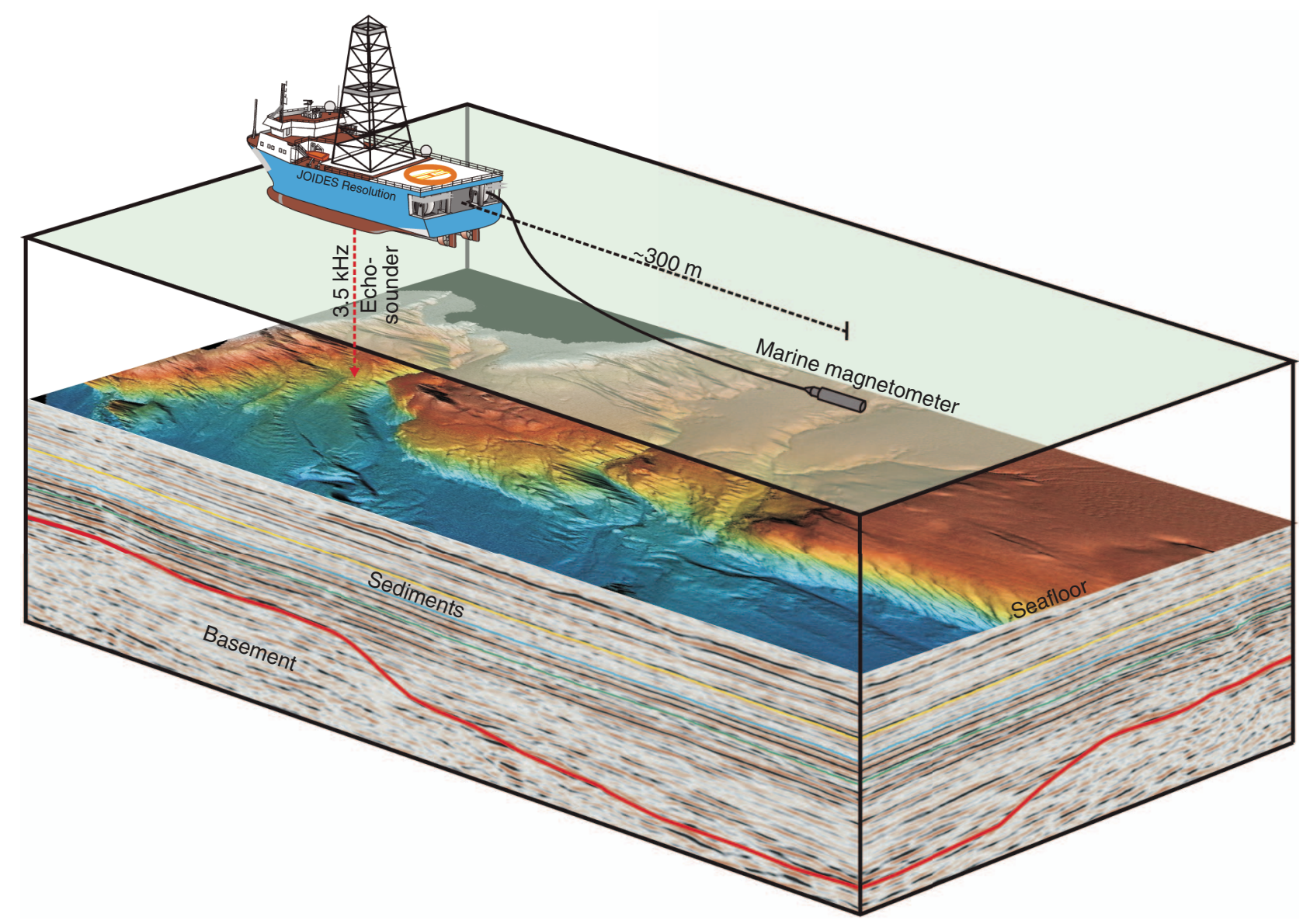


Figure F2. Track line of clockwise circular survey for ship's magnetic heading correction conducted in transit from Site U1349 to U1350. Annotations are time in Universal Time Coordinated. Red dots along track are at 10 min intervals. Contours and colors indicate bathymetric depths using the 30 arc-s resolution GEBCO_08 grid (General Bathymetric Chart of the Oceans, 2008).

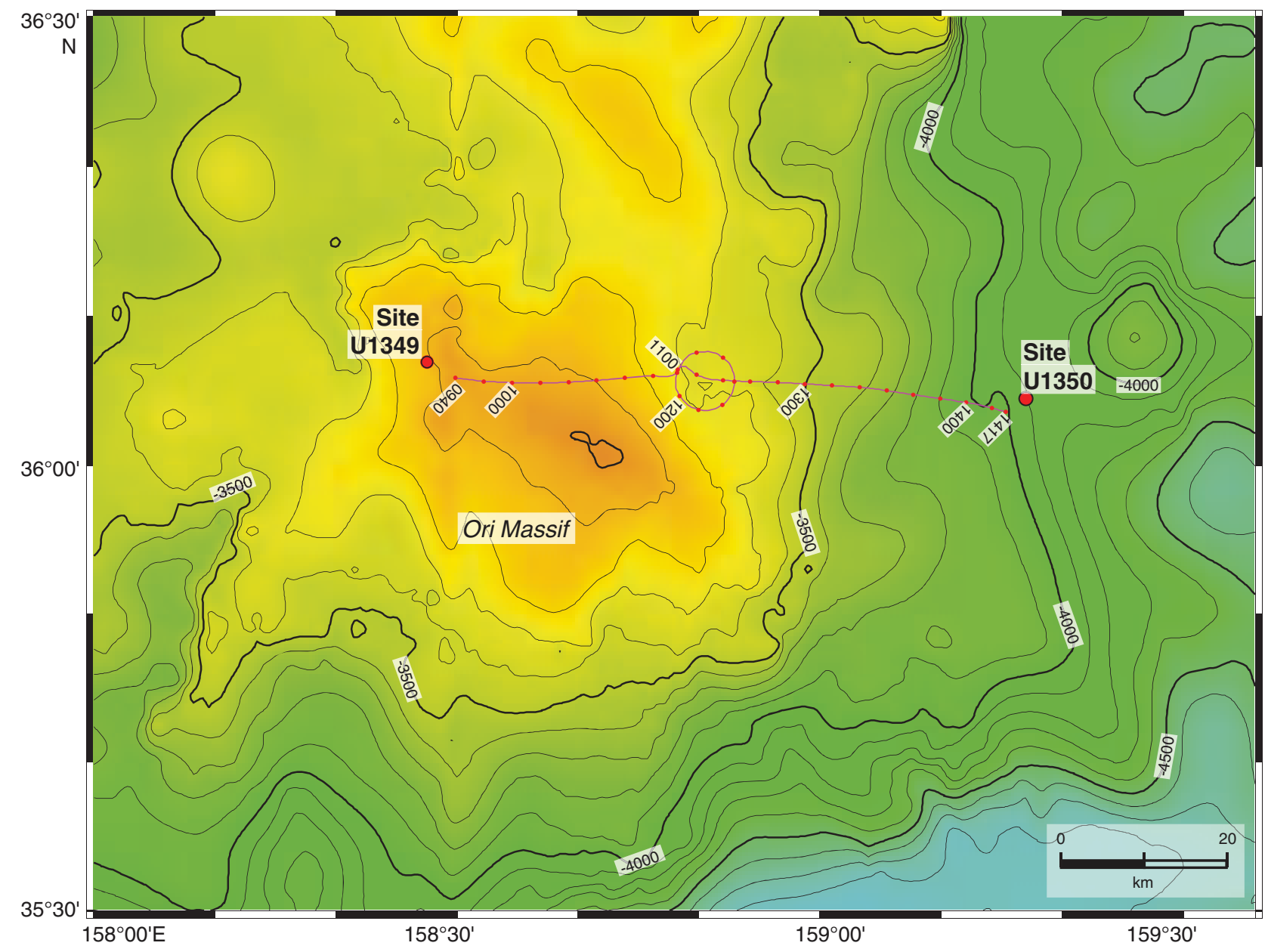


Figure F3. Profiles of International Geomagnetic Reference Field (IGRF), total magnetic field, magnetic anomaly, and bathymetry of the circular survey. Time is Greenwich Mean Time.
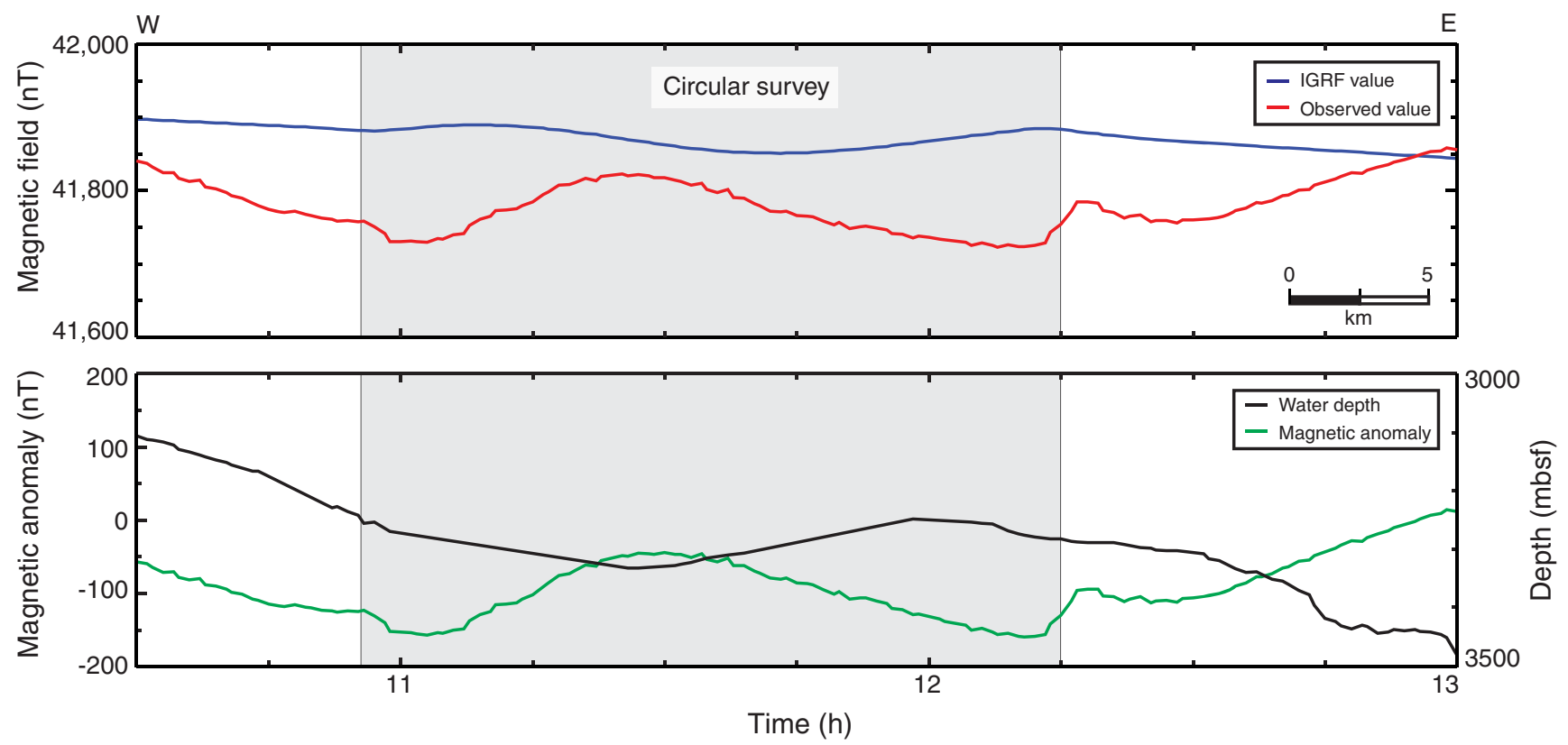
Figure F4. Plot of variation of measured field with ship's heading. Solid red line is computed best fit curve to the measured magnetic field (blue circles) using the formula of Bullard and Mason (1961).

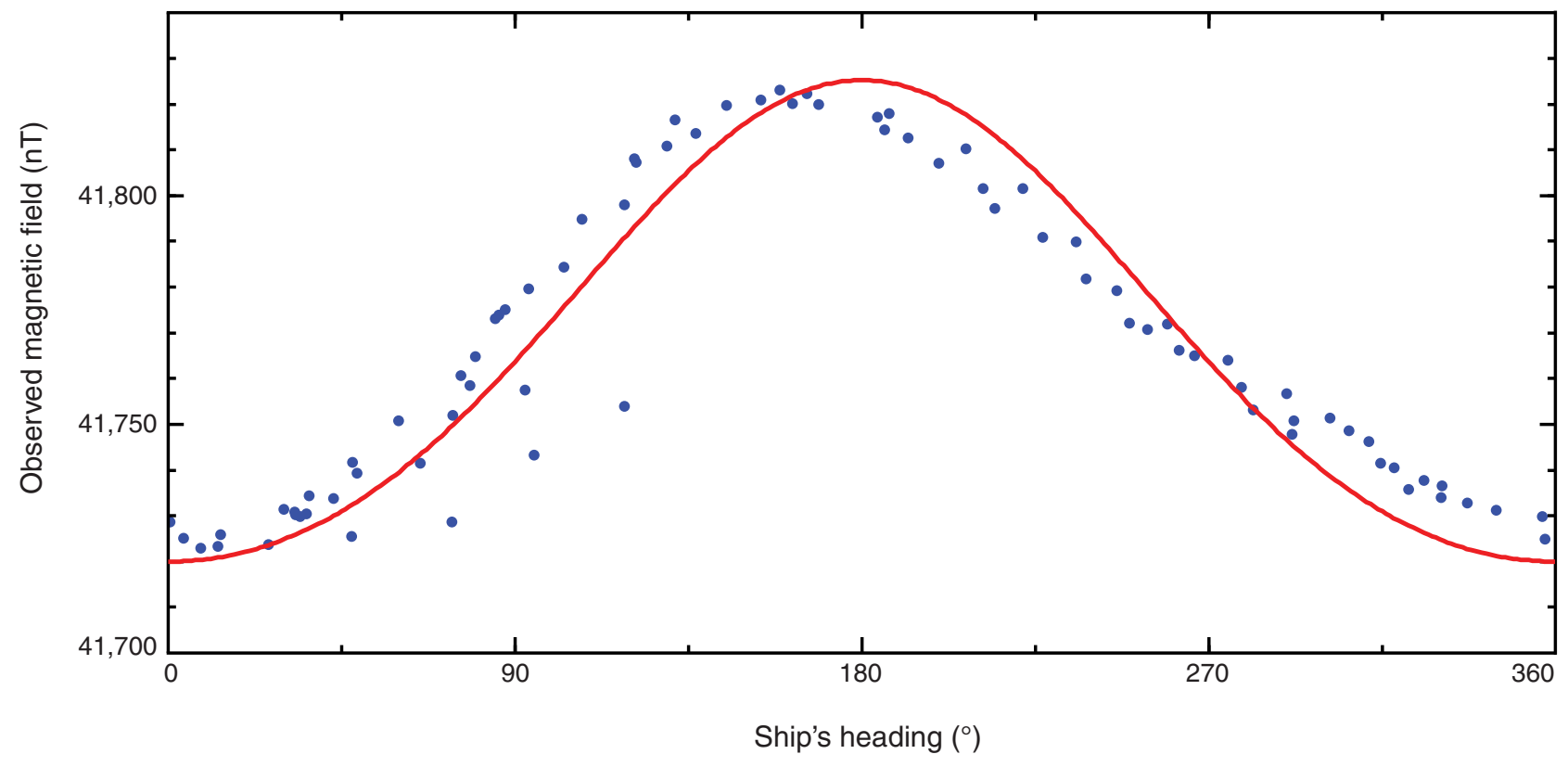


Figure F5. Geophysical track lines collected during Expedition 324. Topography was made using the 30 arc-s resolution GEBCO_08 grid (General Bathymetric Chart of the Oceans, 2008). Red circles = Expedition 324 drill sites, yellow dashed lines $=$ Hawaiian and Japanese magnetic lineations (Nakanishi et al., 1999). CAR = Caroline Islands, $\mathrm{HML}=$ Hawaiian magnetic lineations, JQZ = Jurassic Quiet Zone, JML = Japanese magnetic lineations, $\mathrm{MB}=$ Mariana Basin, MS = Magellan Seamounts, MWS = Marcus-Wake Seamounts, PR = Pocklington Ridge, SB $=$ Solomon Basin, SIA $=$ Solomon Islands arc, $\mathrm{WR}=$ Woodlark Ridge.

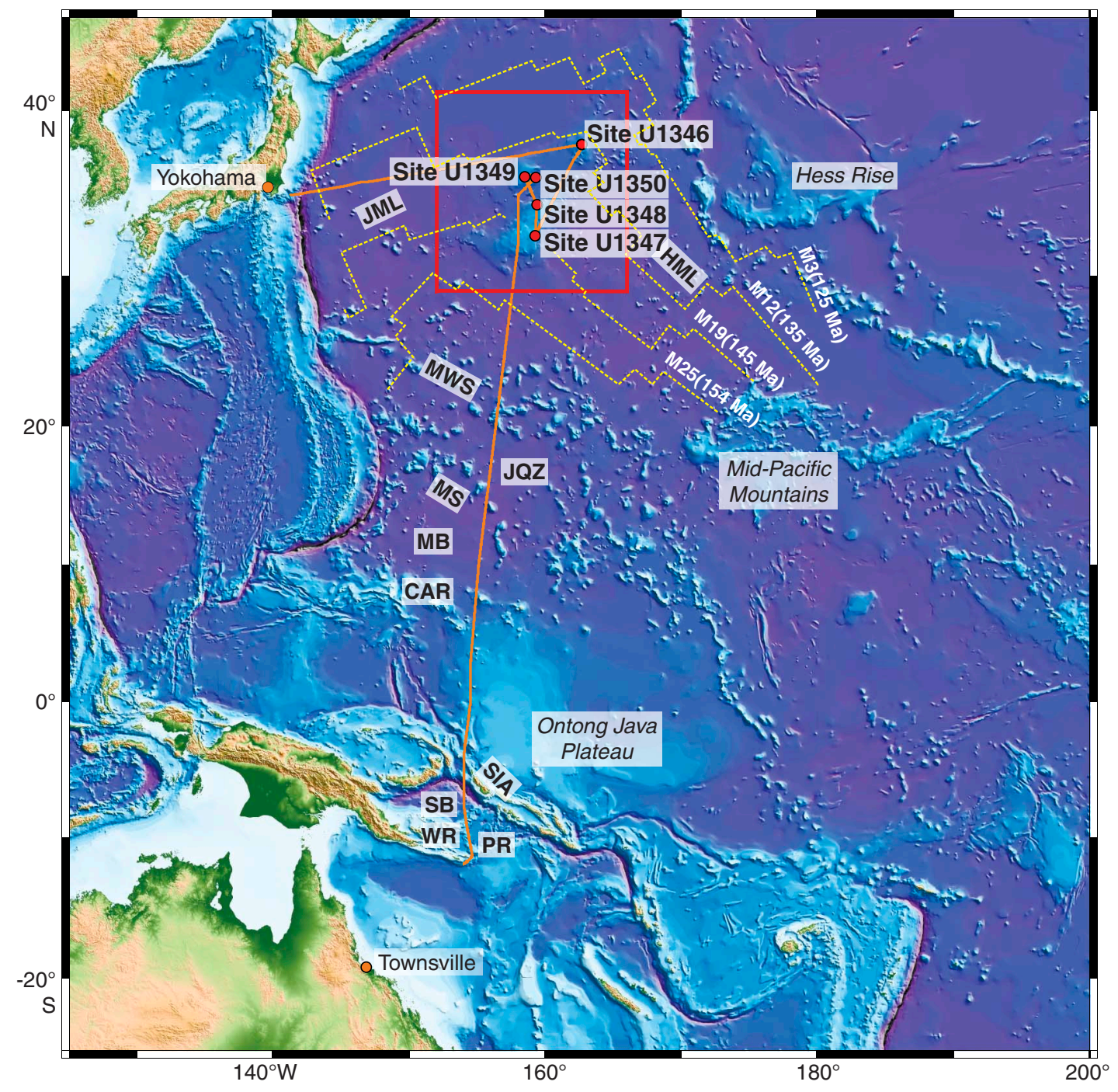


Figure F6. Bathymetric map of the Shatsky Rise using the 30 arc-s resolution GEBCO_08 grid (General Bathymetric Chart of the Oceans, 2008). Solid lines = ship tracks during transits, red circles Expedition 324 drill sites. L1T = Transit EXP324-L1T (Fig. F7), L2T = Transit EXP324-L2T (Fig. F8), L3T = Transit EXP324-L3T (Fig. F9), L4T = Transit EXP324-L4T (Fig. F10), L5T = Transit EXP324-L5T (Fig. F11), L6T = Transit EXP324-L6T (Fig. F12).

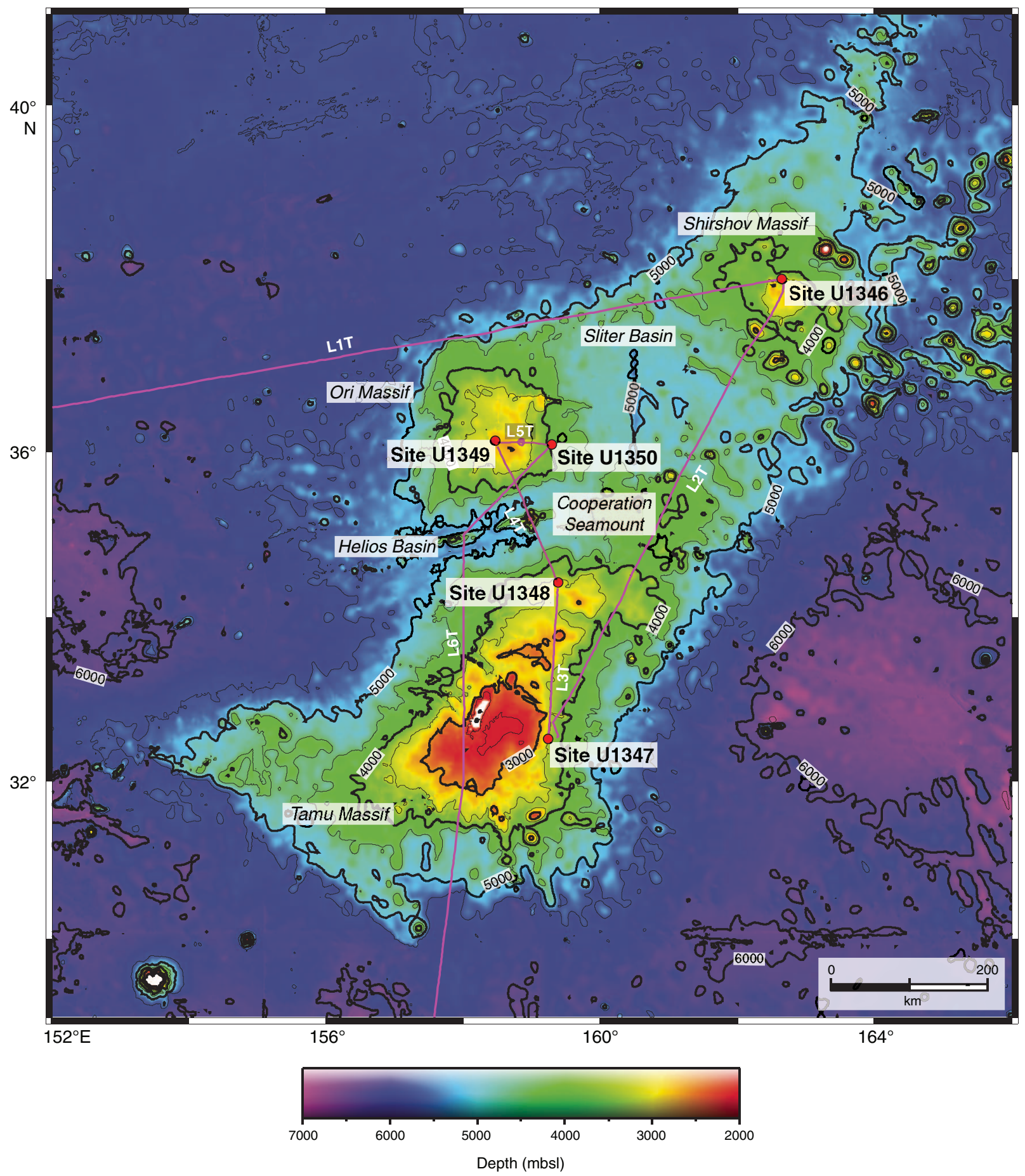


Figure F7. Magnetic anomaly, bathymetry, and CHIRP profiles of Transit EXP324-L1T from Yokohama, Japan, to Site U1346. See Figures F5 and F6 for location.
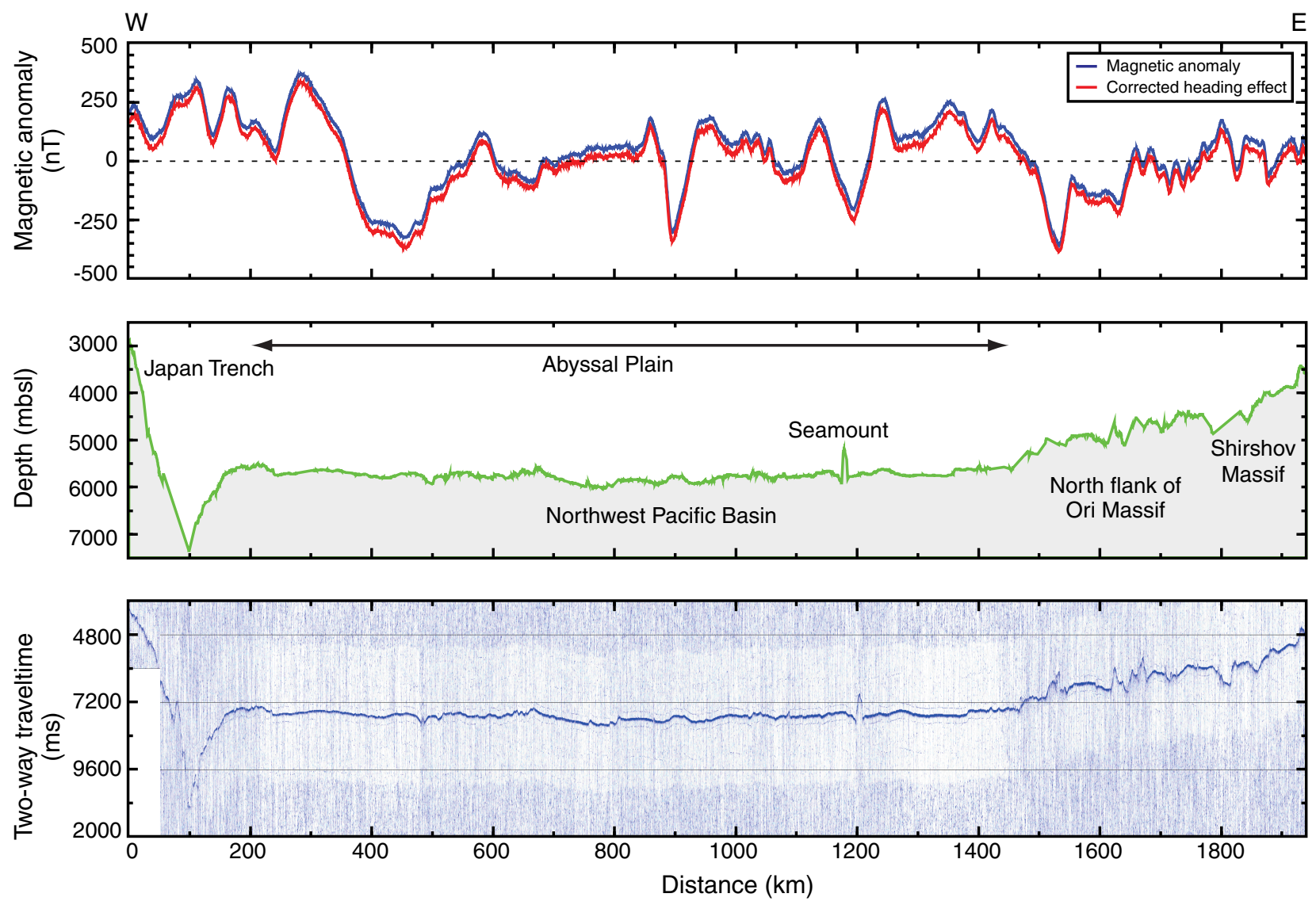
Figure F8. Magnetic anomaly, bathymetry, and CHIRP profiles of Transit EXP324-L2T from Site U1346 to U1347. See Figure F6 for location.
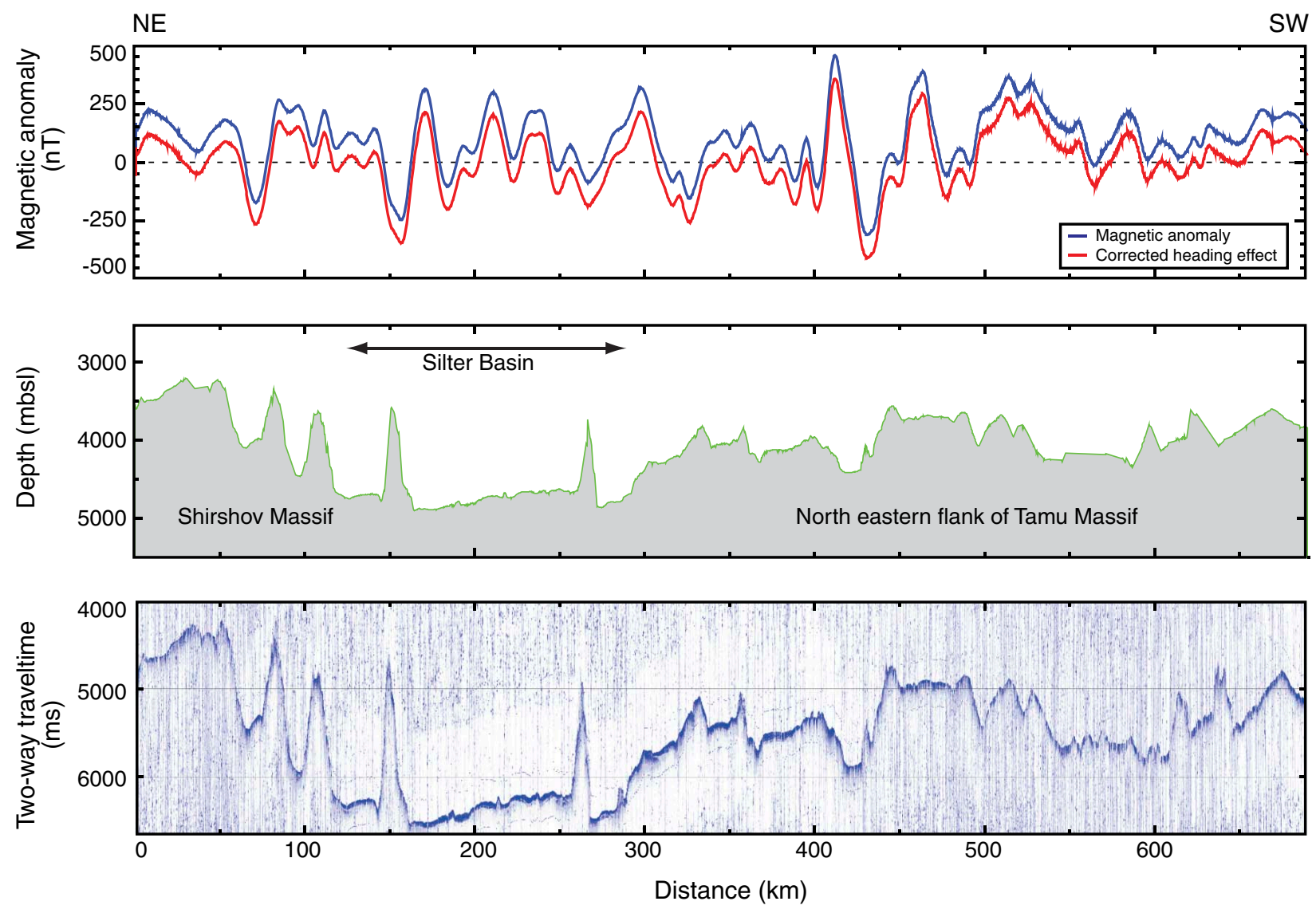
Figure F9. Magnetic anomaly, bathymetry, and CHIRP profiles of Transit EXP324-L3T from Site U1347 to U1348. See Figure F6 for location. Magnetic anomaly line is concealed by corrected heading effect line.
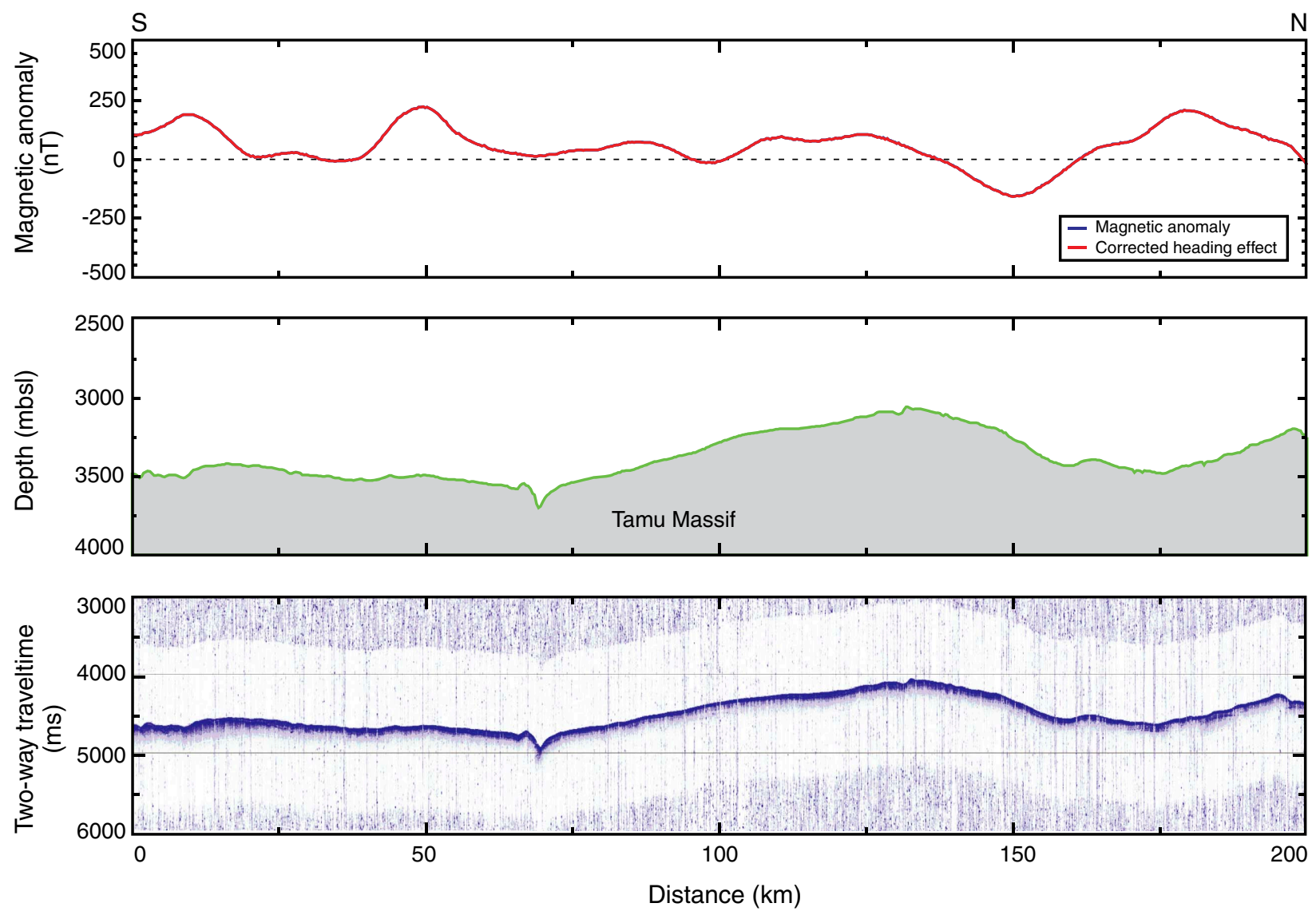
Figure F10. Magnetic anomaly, bathymetry, and CHIRP profiles of Transit EXP324-L4T from Site U1348 to U1349. See Figure F6 for location. Magnetic anomaly line is concealed by corrected heading effect line.
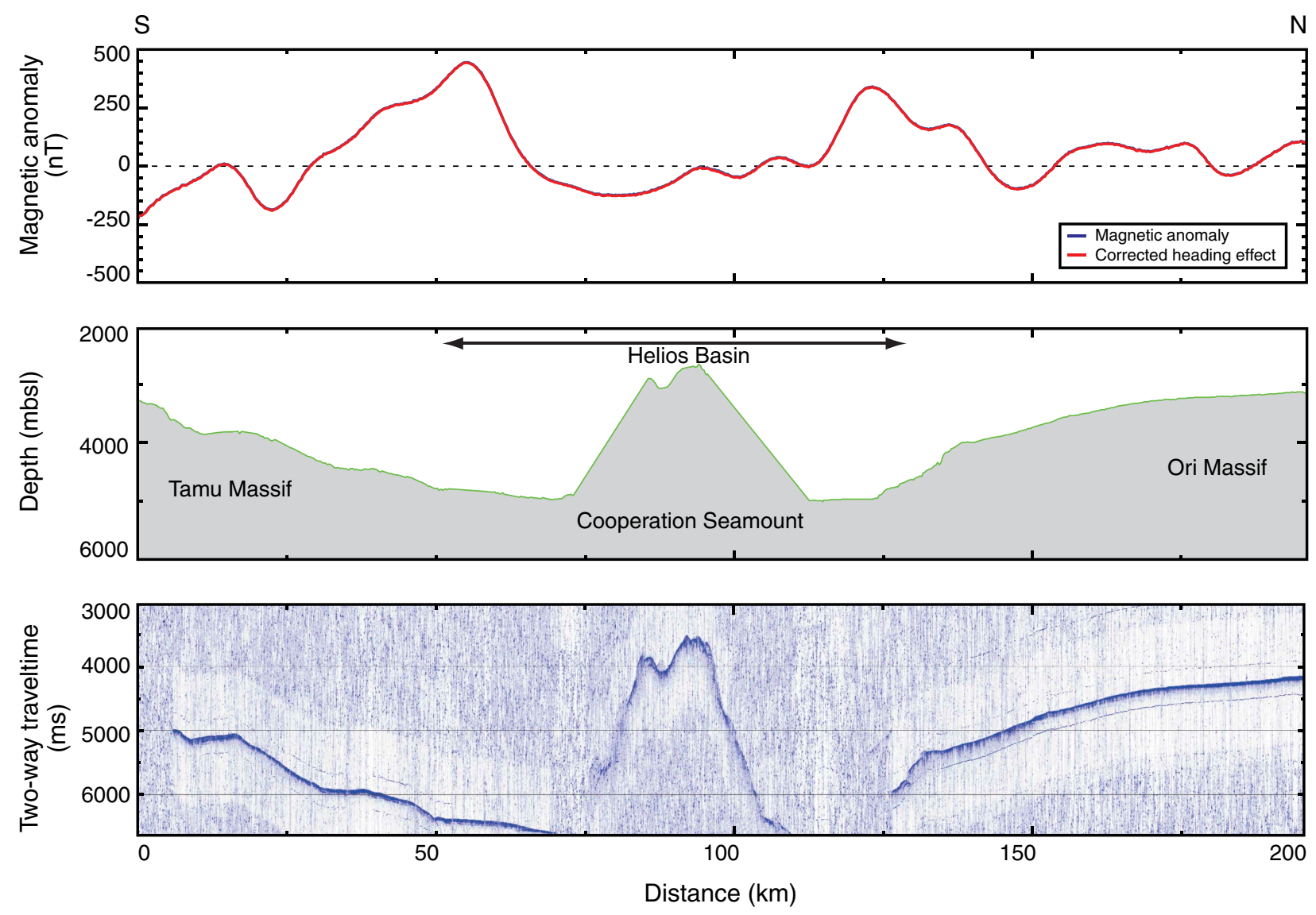
Figure F11. Magnetic anomaly, bathymetry, and CHIRP profiles of Transit EXP324-L5T from Site U1349 to U1350. See Figure F6 for location.
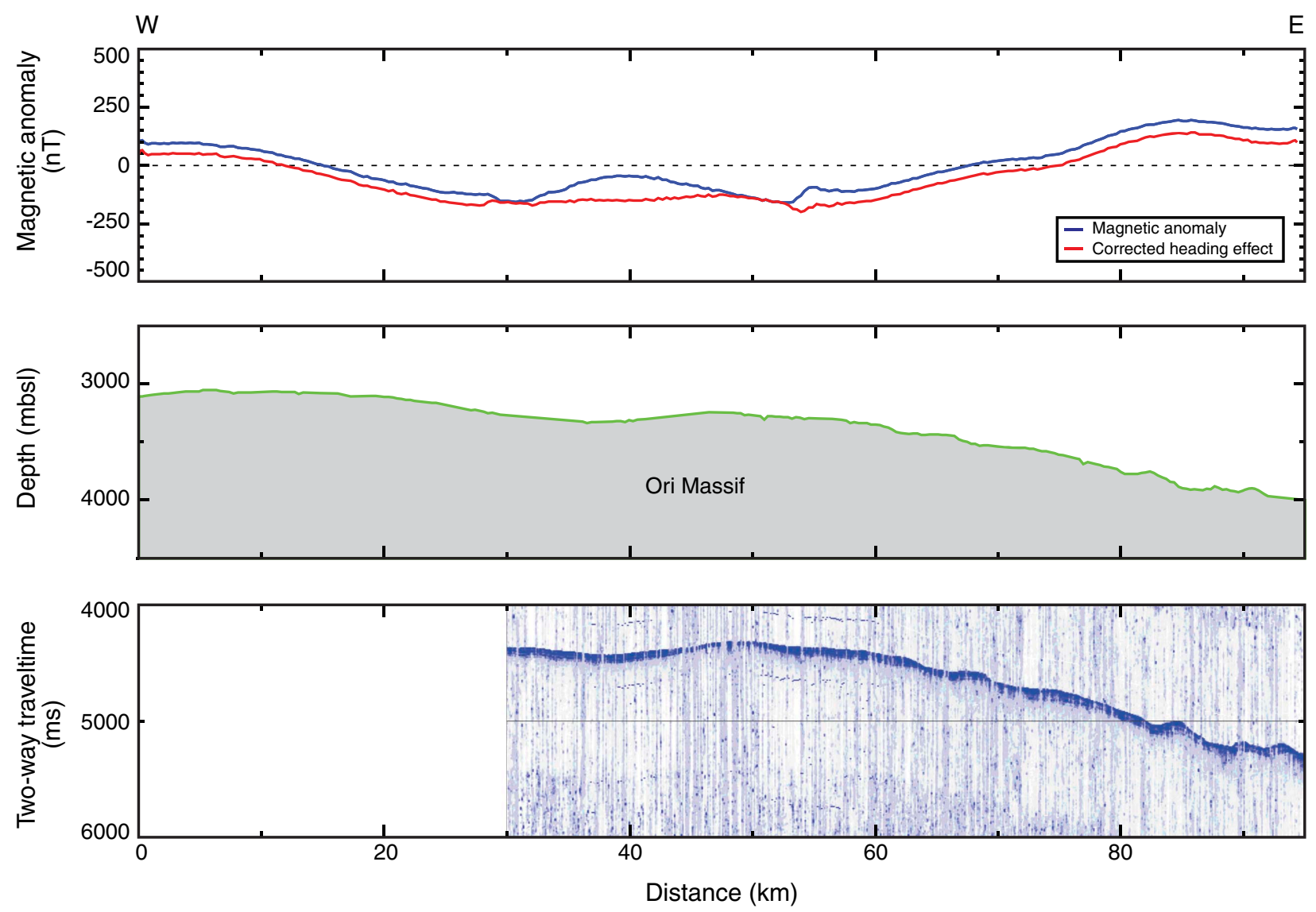
Figure F12. Magnetic anomaly, bathymetry, and CHIRP profiles of Transit EXP324-L6T. See Figures F5 and F6 for location. A. Site U1350 to latitude $25^{\circ} \mathrm{N}$. (Continued on next two pages.)
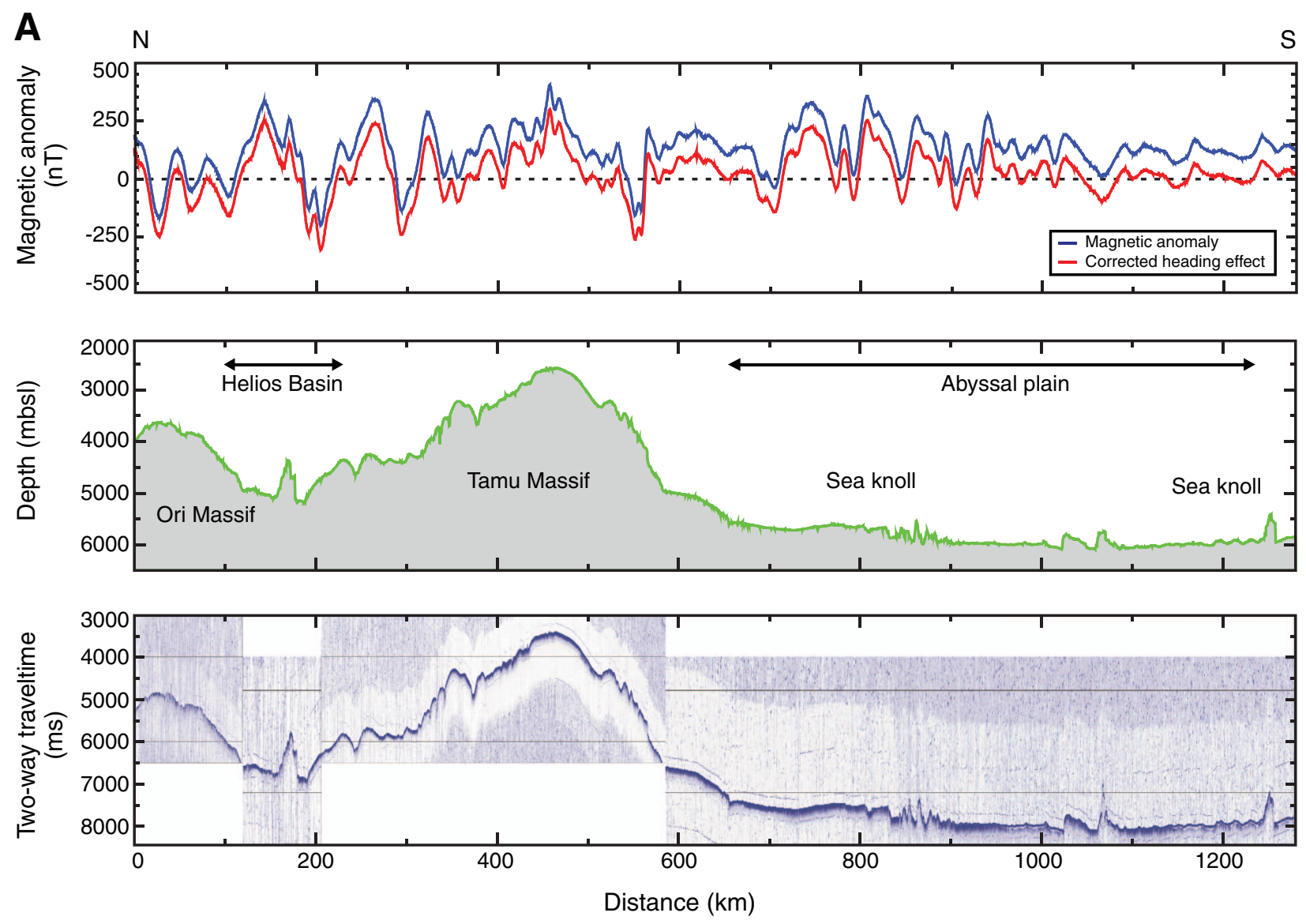
Figure F12 (continued). B. Latitude $25^{\circ}-10^{\circ} \mathrm{N}$. (Continued on next page.)
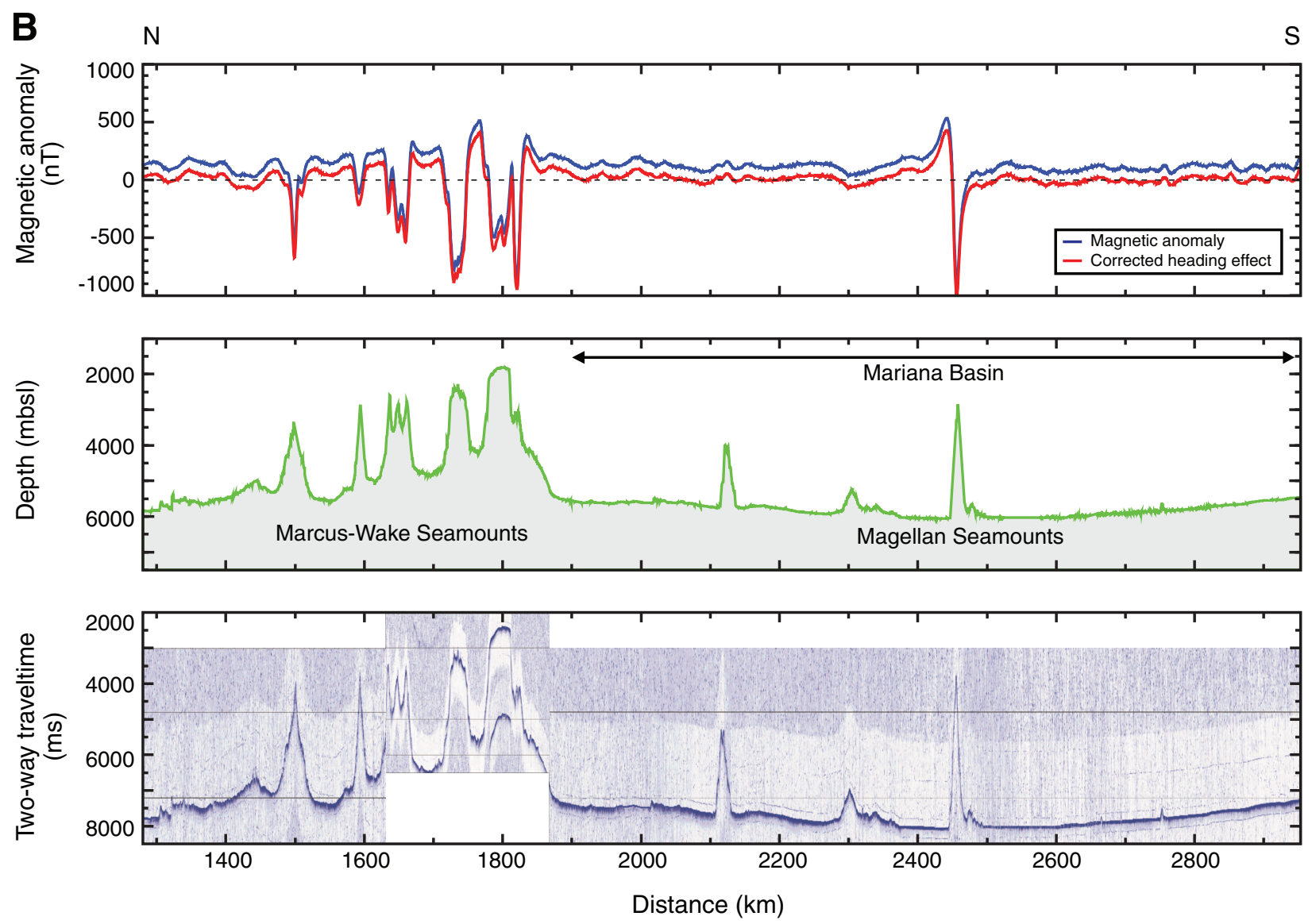
Figure F12 (continued). C. Latitude $10^{\circ} \mathrm{N}-12^{\circ} \mathrm{S}$. Green dashed line $=$ Equator. WR $=$ Woodlark Ridge, $\mathrm{PR}=\mathrm{Pock}-$ lington Ridge.
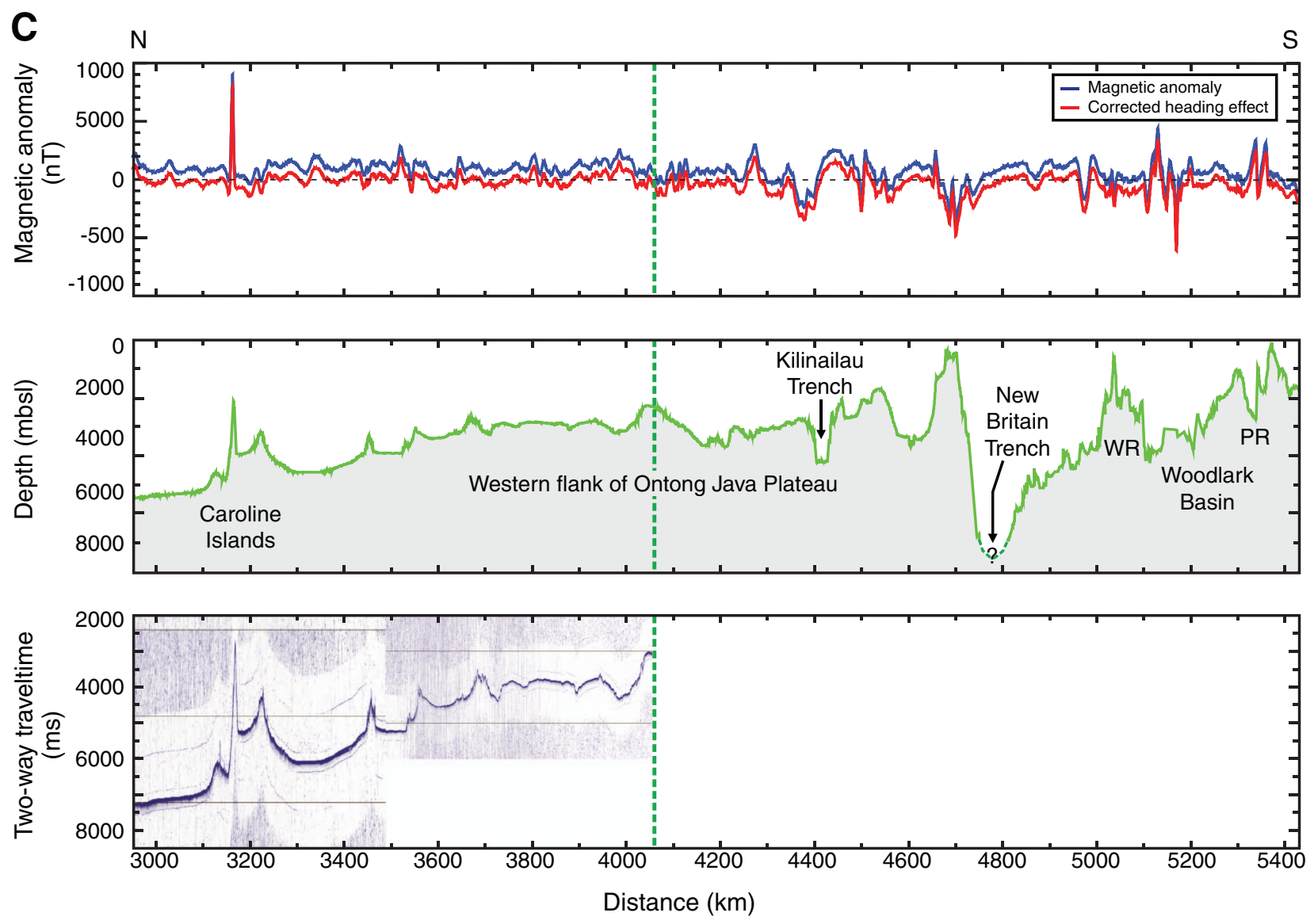
Table T1. Transit segments information for Expedition 324.

\begin{tabular}{cllr}
\hline Transit & \multicolumn{1}{c}{ From } & \multicolumn{1}{c}{ To } & $\begin{array}{r}\text { Distance } \\
(\mathrm{km})\end{array}$ \\
\hline EXP324-L1T & Yokohama, Japan & Site U1346 & 1943 \\
EXP324-L2T & Site U1346 & Site U1347 & 693 \\
EXP324-L3T & Site U1347 & Site U1348 & 203 \\
EXP324-L4T & Site U1348 & Site U1349 & 196 \\
EXP324-L5T & Site U1349 & Site U1350 & 94 \\
EXP324-L6T & Site U1350 & Townsville, Australia & 5430 \\
\hline
\end{tabular}

